\title{
THE CASE FOR A NATIVE AMERICAN 1968 AND ITS TRANSNATIONAL LEGACY
}

\section{INTRODUCTION}

Partly as a result of compartmentalized academic specializations and history teaching, in accounts of the global upheavals of 1968, Native Americans are either not mentioned, or at best are tagged on as an afterthought. "Was there a Native American 1968?" is the central question this article aims to answer. Native American activism in the 1960 s was no less flashy, dramatic or confrontational than the protests by the era's other struggles-it is simply overshadowed by later actions of the movement. While it is seductive to claim that the Native American 1968 was the establishment of the American Indian Movement (AIM) in that auspicious year in Minneapolis, Minnesota, I would caution against constructing this event as the genesis of the Red Power movement.' Using approaches from Transnational American Studies and the history of social movements, this article argues that American Indians had a "long 1968" that originated in Native America's responses to the US government's Termination policy in the 1950s, and stretched from their 'training' period in the 1960s, through their dramatic protests from the late 1960s through the 1970s, all the way to their participation at the United Nations from 1977 through the rest of the Cold War. This intervention in canonized periodization is very much in line with the emerging scholarship

1. For the periodization of Red Power and the larger Native American sovereignty activism during the Cold War, see Smith and Warrior; Johnson; Cobb 2007; and Cobb 2008.

György Tóth

University of Stirling United Kingdom RIAS Associate Editor 
that now includes the transnational dimension and phase of Red Power in what has been dubbed "the global Sixties."

The first section of this study argues that the similarities between Red Power and the other movements of the United States of the 1960s make the radical Indian sovereignty movement a part of the struggles of 1968 . This section highlights the ways in which this struggle was similar enough to the others to be called a Native American 1968. These shared features were its Native radicalism and protest strategies.

The second section of my paper advocates for a certain American Indian 'exceptionalism' and explains how the Native sovereignty movement was different from the other social struggles of the United States in the Sixties. Here I reconfigure the periodization of the Red Power struggle and the American Indian Movement to argue for a "long Native American 1968." Next, I use selected features of American Indian sovereignty rights to make the argument that they place American Indians on the continuum of the liberties of 1968 further away from the classic civil rights of the domestic United States and closer to decolonization, selfdetermination, and national sovereignty in international relations. A full appreciation of this will contribute to our understating that the Native American sovereignty struggle was as much a national liberation movement as a 'domestic' movement for social equality-thus it should also be categorized and interrogated as a part of the Cold War's global movements of decolonization.

1968 Transnational Legacies

With this last move, the study will segue into my final conceptual point: the claim that the Native American 1968 was transnational in more than one way. Here I only explain that American Indians were transnational 'from the inside out' of the history of the United States: their political entities existed before they were colonized by European powers-turned nation states. In my final section I briefly sketch out how one cohort of activists in the long Native American 1968 managed to 'transcend' the US nation state and institutionalized their struggle into what has been called

2. For the use of the term, see Klimke. Recent and current scholarly projects on Native American international activism and the global indigenous movement include Niezen; a doctoral dissertation by Kirová; and works in progress by Paul Rosier and by Daniel Cobb. 
the global indigenous movement. This is the transnational legacy of the Native American 1968.

AMERICAN INDIANS, TOO: THE NATIVE AMERICAN 1968 MOMENT

Anyone making the case for a Native American 1968 has to recognize that there existed what I call a "1968 moment" in American Indian activism. This concerns two specific events of that auspicious year in Native American activism: the Indian participation in the late Martin Luther King's Poor People's Campaign in Washington, D.C. in April through July, and the August 1968 establishment of the American Indian Movement in Minneapolis, Minnesota.

By the late 1960s, various Native nations had been engaged with the challenges faced by US minorities, sometimes combining their forces with the other social movements. Denise Bates traced how American Indian activism in the US South responded to desegregation, the passing of civil rights legislation, and the restructuring of the American political party system. Elsewhere I have established that the radical Native press critiqued the US involvement in the Vietnam War and supported American Indian objections to military service. ${ }^{3}$ Daniel Cobb has shown how by the auspicious year of 1968, various Native American rights organizations had combined their forces with the mainstream Civil Rights Movement. He has discussed that in the spring and summer of 1968 , the late Martin Luther King's Poor People's Campaign included an American Indian contingent both on its organizing board and in its actual demonstrations. ${ }^{4}$

In late April and early May of 1968, the Campaign's board lobbied the major branches of government in Washington, D.C. while several Native American caravans headed for the capital were gathering numbers and momentum by visiting major American Indian population centers. In Washington, co-founder of the radical National Indian Youth Council Mel Thom criticized the US Department of the Interior for denying Native nations

3. Tóth 2016 b, 34, 36-37. However, Native Americans' relationship to military service has been complicated by what Paul Rosier calls "hybrid patriotism." See Rosier 9, 10-11.

4. See Cobb 2008. 
economic opportunity and the right to direct their own education; subsequently the Indians of the Poor People's march held a press conference in front of the United States Supreme Court; and their Solidarity Day on June 19th, 1968 featured a speech by Martha Grass of the Ponca nation. ${ }^{5}$ In their 1968 moment, Native American activists joined the mainstream Civil Rights Movement in their critique of President Lyndon B. Johnson's War on Poverty.

Something else happened in the same year, with much less fanfare. To serve the needs of the tens of thousands of Native Americans who had moved to US big cities on the Termination policy's relocation programs in the previous decade and a half, in August of 1968 in Minneapolis Dennis Banks, Clyde Bellecourt, Eddie Benton Banai, and George Mitchell founded an organization called the American Indian Movement. Relocation had lured Native American families to the big cities with the promise of federal assistance in education, employment, housing, and other services-in order to fully integrate them into mainstream society. The assistance promised did not fully materialize, and being cut off from cultural and social ties that had nurtured them on reservations, Native people not only struggled to find their place, but also faced discrimination both in much-needed services and society, and they were also subject to brutality by law enforcement. To what extent these situations were similar to the deprivation and hopelessness of the black urban ghettos that exploded in the so-called "race riots" of the second half of the 1960 s remains to be studied. However,

1968 Transnational Legacies it is telling that the American Indian Movement originally began as a "patrol" to monitor police behavior towards Indians. ${ }^{6}$

The Native American participation in the Poor People's Campaign in Washington, D.C. and the establishment of the American Indian Movement in Minneapolis, Minnesota make the summer of 1968 a Native American 1968 moment, which concentrated American Indian activism and helped move it into its next, more dramatic and radical stage of campaigning for sovereignty rights. Both the demonstrations and press conferences in the nation's capital and the formation of a group to protect Native Americans

5. Landry, "Today in Native History: Natives Participate in Poor People's Campaign; Protest BIA."

6. Wilson, "AIM Patrol, Minneapolis." 
from discrimination in urban areas signalled a boldness that inaugurated greater militancy by Red Power.

If much of our current understanding of 1968 is shaped by a narrative of radicalization of social movements in their ideologies and strategies, building up to the explosions of that year, then it is well to call this subject of study the radical Native American sovereignty movement. First of all, this struggle was radical in relation to the status quo of US federal Indian policy. Unlike the Civil Rights Movement, which was responding to the progressive ruling of the Supreme Court and its backlash by white supremacists, Red Power was pushing back against a new, but outright regressive, federal policy: Termination. Adopted by Congress in 1954-the same year as Brown vs. Board of Education was handed down-the policy of Indian Termination aimed to end all of the federal government's special relationship with Native nations, including its protection and services to Indians in health, economics, law, and other fields of life.

Termination aimed to immerse Native Americans in the general dominant US society and market as citizens with equal rights and responsibilities-without any of the historical collective rights unique to their political entities. In this, Termination sounded like a progressive, quasi-civil rights policy-but as people in "Indian Country"7 soon found out, it was actually the opposite. The policy had disastrous effects on the nations that it involved. Through congressional legislation, over a hundred tribes were terminated. Indians now had to assume federal, state and local tax burdens, compete with non-Native enterprises in the market place, and obey state laws that conflicted with their treaty rights. Termination meant the withdrawal of virtually all federal services, including food and health assistance, and treaty annuity payments. Without federal assistance and with inadequate means to support themselves, terminated Native communities sunk further into poverty, crime and disease. Termination also ended tribal affiliation for many Indians, which contributed to a sense of hopelessness

7. This is a term used by Native Americans to denote the totality of American Indian communities in the United States. The term is interchangeable with "Native America." For one example of its current use, see the Indian Country Today news portal. 
and uprootedness. Indian land, Native communities and individual Indians now became a burden for the individual states, which had no extra resources to assume jurisdiction and provide for their integration. ${ }^{8}$ It was against this retrograde policy that Native activism mobilized in the 1960 s, setting goals that eventually reached beyond the reinstatement of the status quo ante.

The conventional historians' consensus about Red Power and the American Indian Movement is that they were radical in their goals. ${ }^{9}$ The older, more moderate organizations for Indian sovereignty rights-these included the National Congress of American Indians, established in 1946-most often tried to improve Indian policy case by case, in an incremental fashion, and through litigation in the courts. ${ }^{10}$ The new network of activist organizations were more radical in their goals. When in 1969 the group called Indians of All Tribes took over the island of Alcatraz, they claimed that the 1868 Fort Laramie treaty stipulated that unused government land and property could be taken over by the Indians, so they demanded that the island be granted to them as a place for an Indian university, and a cultural center. ${ }^{11}$ For over a year, the occupiers tried to model their own Native American mini-country in an effort to prove that they were ready for full sovereignty. When in November 1972 four caravans from across Native America converged on Washington, D.C., they issued a "Twenty-Point Position Paper" that demanded the abolition of the Bureau of Indian Affairs (BIA), the government agency that had conducted Indian relations policy for nearly a century and a half. They also demanded the "restoration of a 110-million acre Native land base" by the US federal government by 1976.12 When they occupied the village of Wounded Knee on the Pine Ridge Lakota Sioux Reservation in South Dakota in February of 1973, the American Indian Movement and their Oglala traditionalist allies demanded that the government reinstate the 1868 Fort Laramie Treaty as the basis of relations between the US

8. For a case of the effects of Termination on a specific Native nation and their responses in activism, see Deer.

9. See Smith and Warrior; Johnson; Cobb 2007; and Cobb 2008.

10. See Cowger, Wilkinson.

11. Smith and Warrior 24, 28-29; The Alcatraz Proclamation.

12. Trail of Broken Treaties 20-Point Position Paper. 
government and the Sioux Indians. Had they fully succeeded, the federal government would have had to roll back its post-treaty legislation and restore to the Sioux Nation much of the territories of the current states of Montana, Wyoming, North and South Dakota, and Nebraska.13 These immediate goals were so radical in their reach that, had they succeeded, they would have fundamentally reconfigured Native American territory and rights in the United States. For their advocates, they were as realistic as that of forcing the United States government to end the war in Vietnam and pull out all American troops from Southeast Asia. Yet they were not the most radical goals-those will be discussed in the next section.

The new cohort of Native rights organizations' protest strategies were no less radical. Older, more moderate groups like the National Congress of American Indians claimed that "Indians do not demonstrate"-they rather lobbied government.14 The National Indian Youth Council, the American Indian Movement, and their allied groups borrowed from the other social movements in developing a repertoire of direct action methods. They marched and picketed, but could not generally rely on these forms because of their low numbers: the total Native American population was about 600,000 in a general population of 250 million. The two protest forms they used that most resembled those of the other social movements were the so-called 'ins,' and takeovers and occupations. Like the lunch counter sit-ins and Freedom Rides of the Civil Rights Movement, the Native fish-ins of the 1960s US Northwest asserted Indians' off-reservation rights by exercising them in the face of discrimination and violence. Like the free speech and other movements' occupations, Native American takeovers and occupations targeted sites of historical importance, ${ }^{15}$ or administrative centers or transportation hubs, where they disrupted the machinery of government, and attracted and manipulated the media to publicize their causes. These included the Indians of all Tribes' 1969-71 occupation of Alcatraz, their joint project

13. "Declaration of Continuing Independence" map.

14. Shreve; Cobb 2008.

15. For a study of the Native American use of US national historical memory for publicizing American Indian sovereignty rights, see Tóth 2016 a. 
with the American Indian Movement in the 'hijacking' of the Thanksgiving commemoration ceremonies at Plymouth, Massachusetts in 1970; Red Power's camping out and defacing the presidents' portraits on Mount Rushmore, South Dakota in the same year; their takeover of the Bureau of Indian Affairs headquarters in Washington, D.C. in November 1972; and the occupation of the village of Wounded Knee in South Dakota for over two months in 1973 by AIM and their local Oglala allies.

Finally, like the Black Panthers, the radical Native sovereignty movement not only rhetorically advocated self-defense by Indians against those who would hurt them-they also acted on their words. The American Indian Movement declared themselves a "warrior society," ready to go to defend any Native community who asked for their protection. ${ }^{16}$ Especially the men of AIM lived up to their own image as gun-toting, 'bad' Indians. At the BIA building in Washington, D.C. in 1972, at the courthouse of Custer, South Dakota in 1973, in the village of Wounded Knee in 1973, and on the Jumping Bull Ranch of South Dakota in 1975, Native activists violently clashed with security, police, the FBI, and even the United States military, resulting incasualties and deaths. The federal response was equally serious. The government prosecuted some 200 Native activists who were involved in the siege of Wounded Knee in the spring of 1973, and hunted down, tried and convicted Leonard Peltier for his role in the killing of two FBI agents in June 1975. Like the other social and political movements of the 1960 s, the radical Native sovereignty

1968 Transnational Legacies

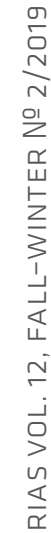
movement was also subject to federal surveillance, the planting of informers, law enforcement framing and negligence in criminal investigations and court proceedings. These only contributed to the terrible wave of violence that decimated radical activists on the Pine Ridge Reservation, where government manipulation likely turned AlM members against one another."

AN 'EXCEPTIONAL/IST' NATIVE AMERICAN 1968

Yet the Native American sovereignty movement was different from the other social struggles of the United States in this period

16. Banks and Erdoes 58; Smith and Warrior 137-138.

17. See Churchill, Matthiessen, Stern, and Smith and Warrior. 
in at least two ways. Firstly, because for a long time they had received less media attention and awareness in mainstream US society, American Indian causes seemed to arrive on the national scene later and in more radical forms. The 1969-71 occupation of Alcatraz garnered regional, some national and even some international media coverage due to its duration; the 1972 takeover of the BIA building in Washington did similarly well also because it took place in the center of power and just before the presidential election; while the spring 1973 siege of Wounded Knee exploded onto the national and international scene both because it lasted over two months, allowing for the convergence of the media on the village and the staging of solidarity events by supporters-including an air drop of food on the village, and a demonstration at the United Nations in New York City. In other words, while the radical Indian sovereignty movement did have a 1968 "moment," I argue that they had a "long 1968" that began in the 1960s, came to the fore between 1969 and 1975, and morphed into a variety of causes and networks in the later 1970s. This later period's landmark events were more transnational and international in character, and this is why before the emergence of work by scholars like Daniel Cobb, Ronald Niezen, Kevin Bruyneel, Lucie Kyrova and this author, this second half of the "long Native American 1968" was much less recognized in historiography. This period will be discussed in the last section of this article.

There is another aspect in which I can play an 'exceptionalist' card $^{18}$ in arguing that the radical Indian sovereignty struggle was

18. I use the term 'exceptionalism' as a meta-joke as much as to make a point about the uniqueness of Native Americans' collective rights in US democracy. Exceptionalism is a feature of some early 20th century, then Cold War and 'imperial' politics and scholarship in US History and American Studies. Its elements include claims that the United States is a nation unique in its origins, development as a nation state (in its cultural, political, social, and other characteristics), that it should be understood on its own terms as separate from all other nations, regions and continents. The sometimes unstated corollary of US exceptionalism is that the United States has a national mission in the world, and this consists of both modeling and assisting in spreading its own characteristics, especially its system of democracy and free enterprise. The popular and scholarly literature of US exceptionalism is voluminous and simply too long to include here. 
different from the other rights movements of the 1960s. It was unique in the kind of rights it fought for. Already during its "1968 moment," the Native activists of the Poor People's Campaign's lobbying committee explained to the government and the press in Washington in April 1968 that

[... we make it unequivocally and crystal clear that Indian people have the right to separate and equal communities within the American system-our own communities, that are institutionally and politically separate, socially equal and secure within the American system. ${ }^{19}$

The paradox of the American Indian rights struggle is that only one part of it was for civil rights, the rights to integrate into US society as individuals, free from discrimination based on one's background or group origins. For the most part, the Native American activists of the long 1968 were fighting for collective rights known as sovereignty: the right to collectively own land, the right to tribal jurisdiction in law and law enforcement, the right to have a tribal government as their political decision-making mechanism, the right to exercise hunting and fishing rights on and outside of Indian reservations, the right to tribal control and collective self-representation in culture. These kinds of rights place American Indians on the continuum of the liberties of 1968 further away from the classic civil rights of the domestic United States and closer to what we understand as decolonization, selfdetermination, and national sovereignty in international relations.

1968 Transnational Legacies

The American Indian struggle was different from the other US domestic movements of 1968 because of the uniqueness of Native Americans' historical status. American Indians were originally prenational collectives before the arrival of Europeans; subsequently they were independent nations, recognized as such through over a century of treaty making between them and European powersturned North American nation states. Only in the mid-to late19th century did US law and government begin to succeed in forcing their redefinition of Native American status on Indians-making

19. Committee of 100, "A Sickness Which Has Grown to Epidemic Proportions" (April 1968), in Cobb 2015, 149-151. Special thanks to Reetta Humalajoki for the quote and source. 
them nations "domestically dependent"20 on direct services from the federal government in return for them having given over most of their land base for Euro-American settlement. What the "long Native American 1968" fought for was not to lose their collective status in return for civil rights in Termination, but to reinstate some of their collective sovereignty rights that had been recognized in hundreds of historical treaties. Because of this fundamental difference, the 'inside-outside' position of American Indian history and rights in the United States, the Native American sovereignty struggle was both part of the domestic rights movements of the 1960s and it was a cause of decolonization and national liberation qualitatively different from civil rights and equality in US citizenship.

Thus, the American Indian activists of the long 1968 were campaigning for sovereignty rights; and they were pushing as hard and as far as these rights could be carved out from the US government and society. This is why their most radical cohort were aiming for the logical extreme end point of sovereignty: fully independent countries. Roxanne Dunbar-Ortiz recalled that between 1974 and 1982, "[i]nternal discussions among IITC [the International Indian Treaty Council] activists revolved around the question of self-determination, generally called 'sovereignty.' Clearly, the already existing model of independent nations emerging from colonialism did not neatly fit the situations of Indian peoples in the Americas." Nevertheless, she pointed out that reservationsize island countries had gained United Nations membership-and that the territory of the Navajo was larger than most of these. ${ }^{21}$ At a February 1975 meeting between Treaty Council activists and international lawyers, 22

\footnotetext{
20. Cherokee Nation v. Georgia, 30 US (5 Pet.) 1 (1831)

21. Dunbar-Ortiz 33-34. Emphasis in original.

22. In her Indians of the Americas, Roxanne Dunbar-Ortiz cites this document as "From the Archives of the International Indian Treaty Council, New York. File dated February, 1975: Report from Meeting of International Lawyers." Since I did not find this document in the Treaty Council's San Francisco Office, I have to assume that this file fell casualty to office downsizing, or water damage, both of which occurred during the Treaty Council's 44 years in existence. Records of the International Indian Treaty Council.
} 
"[d]iscussions of independence centred on the Indian people under US and Canadian jurisdiction, with little comparative analysis of other areas of the Americas, although the assumption was that independence was the ideal goal. The principal barrier to pursuing the course of independence was identified as the US government."23

\section{THE TRANSNATIONAL DIMENSION OF THE NATIVE AMERICAN 1968}

This brings US to the final point: the transnational dimension and legacy of the Native American long 1968-in its second half of events. Since one of their ultimate goals was to attain the option for decolonization into fully independent countries, the radical Native sovereignty movement switched strategies: after years of exhausting and costly direct confrontations with the US government, Indian activists decided to bypass "Uncle Sam"24 and build and utilize a transnational network. One year after the siege of Wounded Knee, the first International Indian Treaty Council conference on the Standing Rock Sioux Reservation in 1974 laid down a program of reasserting Native American sovereignty through transnational diplomacy. The goal of the American Indian Movement's "international work" was to force the US government to recognize the treaty rights of Native nations as law, as well as to attain status in the United Nations for Native American nations, pending their full decolonization. Because of the power of nation states and the inertia of the United Nations, in the following three years radical Native activists had to scale back their project

1968 Transnational Legacies

23. Dunbar-Ortiz 34. Emphasis added.

24. Originating in political cartoons in 19th century newspapers, the figure of "Uncle Sam" has served to represent the United States government. 
helped strengthen the global indigenous rights movement.

This is the transnational legacy of the Native American long 1968.

\section{THE LEGACIES OF THE NATIVE AMERICAN 1968}

The domestic legacy of the Native American long 1968 is evident in the current sovereignty rights régime of the United States. In tandem with the more moderate Native rights organizations like the National Congress of the American Indians, the radical edge of the Red Power Movement succeeded in bending federal Indian policy away from Termination and regaining some important sovereignty rights. In the period between Wounded Knee 1973 and the end of the Cold War in 1990, the US nation state passed the Indian Self-Determination and Education Assistance Act of 197525; the American Indian Religious Freedom Act of 197826; the Indian Child Welfare Act of 197827; the Indian Caming Regulatory Act of $1988^{28}$; the Aleut Restitution Act of 1988; the Native American Graves Protection and Repatriation Act of $1990^{29}$; the Indian Arts and Crafts Act of $1990^{30}$; and the Native American Languages Act of $1990^{31}$. Yet the Indian Claims Limitations Act of $1982^{32}$ and some of the Indian land claims settlements extinguished Native title to land on what is now US soil. On balance, directly or indirectly, the mainstream as well as the radical Indian sovereignty movement successfully pressured the US government for progressive legislation on Native rights. The fact that Native American health care provisions and adoption law are currently under assault by the US government shows the extent to which the Native American long 1968 managed to carve out and enshrine Indian sovereignty rights. ${ }^{33}$

\footnotetext{
25. "Subchapter II-Indian Self-Determination and Education Assistance."

26. "'We Also Have a Religion."

27. "About ICWA."

28. "Indian Gaming Regulatory Act."

29. "H.R.5237-Native American Graves Protection and Repatriation Act."

30. "Indian Arts and Crafts Act of 1990."

31. "S.2167-Native American Languages Act."

32. "H.R.7356-Indian Claims Limitation Act of 1982."

33. Diamond, "Trump Challenges Native Americans' Historical Standing"; Flynn, "Court Strikes Down Native American Adoption Law, Saying it Discriminates against Non-Native Americans."
} 
The transnational legacy of the Native American long 1968 is the global mechanism of indigenous human rights under the United Nations. After years of repeated lobbying and petitioning, the 1977 arrival of American Indian delegates in the United Nations revitalized the world body's languishing attempts to accommodate these transnational groups in the Americas. José R. Martínez Cobo's "Study of the Problem of Discrimination against Indigenous Populations" was finally published in 1982, a whole decade after it was commissioned. First created during the 1977 NGO conference, the "Declaration of Principles for the Defense of the Indigenous Nations and Peoples of the Western Hemisphere" went through several incarnations and subsequently served as the basis of the Declaration of Principles for the Rights of Indigenous Peoples ${ }^{34} \mathrm{drafted}$ between 1985 and 1993 by the Working Group on Indigenous Populations, and adopted by the UN General Assembly in 2007.35 Created in 1981 and convened for the first time the following year, the UN Working Group on Indigenous Populations (WGIP) opened the door wider to indigenous rights organizations both vying for UN NGO status and not affiliated with the world body. ${ }^{36}$ The broad mandate of the WGIP and the increasing number of participating indigenous groups gradually developed this forum into the Special Rapporteur on the rights of indigenous peoples (2001-), ${ }^{37}$ the Permanent Forum on Indigenous Issues (2002-), ${ }^{38}$ and the Expert Mechanism on the Rights of Indigenous Peoples

1968 Transnational Legacies (2007-). ${ }^{39}$ Together, these mechanisms now function as an indigenous rights régime in the United Nations, studying, reporting and advising about indigenous issues around the world, and using their supranational status to pressure national governments to improve their treatment of Native peoples and respect their rights to self-determination-the right to define their own political status, including through forms of full integration or autonomy

34. Dunbar-Ortiz 2005, 38. Also see Dunbar-Ortiz, "What Brought Evo Morales to Power?," xiii.

35. Wiessner, "Introduction."

36. Dunbar-Ortiz, "What Brought Evo Morales to Power?," xvii.

37. Special Rapporteur on the Rights of Indigenous Peoples website.

38. United Nations Permanent Forum on Indigenous Issues website.

39. The Expert Mechanism on the Rights of Indigenous Peoples website. 
in another nation state. ${ }^{40}$ The development of these forums with their many indigenous, UN, governmental and other NCO participants redefined the terms and the scope of the discussions from "Indian" to "indigenous," from "nations" and "people" through "populations" to "peoples." These mechanisms, however, could not have been created without the hard work, bravery, and persistent embodied transnational diplomacy of the activists of the Native American long 1968.

\section{CONCLUSION}

This article has argued that, through the Indian participation in the late Martin Luther King's Poor People's Campaign in Washington, D.C. in April through July, and the August 1968 establishment of the American Indian Movement in Minneapolis, Minnesota, the Native American "1968 moment" concentrated American Indian activism and helped move it into its next, more dramatic and radical stage of campaigning for sovereignty rights. Native radicalism and protest strategies like the takeover and occupation and "ins" make American Indian sovereignty activism a part of the mainstream US domestic social movements of the long 1960s through their shared features. Yet the Native American sovereignty movement was different from the mainstream rights struggles because it advanced collective legal status, which is further away on the continuum from civil rights. I argued that Native American transnationalism and sovereignty rights make the American Indian long 1968 as much a national liberation struggle as a US domestic rights movement, thus it was a decolonization movement in addition to one for American citizenship. This highlights the fact that the Cold War's decolonization struggles took place not only in 'the Third World,' but also within the very heart of the First World, specifically in the United States and Canada. ${ }^{41}$ The final part of my article assessed the legacies of the Native

40. The United Nations Declaration on the Rights of Indigenous Peoples.

41. As early as in his 1974 book The Fourth World: An Indian Reality, (Canadian) First Nations thinker and activist Ceorge Manuel argued that in addition to the Cold War geopolitical divisions, a fourth world existed, inhabited by indigenous nations, often within or across the modern nation states. Manuel. To the national liberation/decolonization struggles of Native America should 
American long 1968-in the domestic sovereignty legislation of federal Indian law, and in the supra-national and world governance mechanism for indigenous human rights. These rights régimes were historically constructed, and they exist not only in the law books, but in their enactment, performance and enforcement. They must not be taken for granted, but exercised and protected, lest they be eroded or actively rolled back. and possibly others. 
WORKS CITED

"About ICWA." National Indian Child Welfare Association. Online. <https://www.nicwa.org/about-icwa/>. Accessed October 27, 2018.

"The Alcatraz Proclamation." Native Media Center. University of North Dakota. Online. <https://arts-sciences.und.edu/native-mediacenter/_files/docs/1950-1970/1969alcatrazproclamation.pdf>. Accessed October 20, 2018.

Banks, Dennis and Richard Erdoes. Ojibwa Warrior: Dennis Banks and the Rise of the American Indian Movement. University of Oklahoma Press, 2004.

Bates, Denise. The Other Movement: Indian Rights and Civil Rights in the Deep South. Tuscaloosa: The University of Alabama Press, 2012.

Cherokee Nation v. Ceorgia, 30 US (5 Pet.) 1 (1831). Online. <https:// supreme.justia.com/cases/federal/us/30/1/>. Accessed October 20, 2018.

György Tóth

University of Stirling United Kingdom

RIAS Associate Editor

Churchill, Ward. Agents of Repression: The FBI's Secret War against the Black Panther Party and the American Indian Movement. South End Press, 1988

Cobb, Daniel. "Talking the Language of the Larger World: Politics in Cold War (Native) America." Beyond Red Power: American Indian Politics and Activism since 1900, edited by Daniel Cobb and Loretta Fowler, School for Advanced Research, 2007. 161-177.

Cobb, Daniel. Native Activism in Cold War America: The Struggle for Sovereignty. University Press of Kansas, 2008.

Cobb, Daniel, ed. Say We Are Nations: Documents of Politics and Protest in Indigenous America since 1887. The University of North Carolina Press, 2015.

Cowger, Thomas W. The National Congress of the American Indians: The Founding Years. The University of Nebraska Press, 1999.

"Declaration of Continuing Independence" map. Roger A. Finzel American Indian Movement Papers. Center for Southwest Research, Zimmerman Library, University of New Mexico.

Deer, Ada. "Ada Deer (Menominee) Explains How Her People Overturned Termination, 1974." Major Problems in American Indian 
History, edited by Albert L. Hurtado, Peter Iverson, William J. Bauer, Jr., Stephen Kent Amerman, Cengage Learning, 2014 (3rd edition), 495-497.

Diamond, Dan. “Trump Challenges Native Americans' Historical Standing." Politico.com, April 22, 2018. Online. <https://www. politico.com/story/2018/04/22/trump-native-americanshistorical-standing-492794>. Accessed October 27, 2018.

Dunbar-Ortiz, Roxanne. Indians of the Americas: Human Rights and Self-Determination. Zed Books Ltd, 1984.

----- Blood on the Border: A Memoir of the Contra War. South End Press, 2005.

------. "What Brought Evo Morales to Power? The Role of the International Indigenous Movement and What the Left is Missing." Counterpunch, February 10, 2006. Online. <https://www. counterpunch.org/2006/02/10/what-brought-evo-moralesto-power/>. Accessed October 27, 2018.

The Expert Mechanism on the Rights of Indigenous Peoples website. Online. <http://www.ohchr.org/EN/Issues/IPeoples/EMRIP/ Pages/EMRIPIndex.aspx>. Accessed October 27, 2018.

Flynn, Meagan. "Court Strikes Down Native American Adoption Law, Saying it Discriminates against Non-Native Americans." Washington Post, October 10, 2018. Online. <https://www. washingtonpost.com/news/morning-mix/wp/2018/10/10/ court-strikes-down-native-american-adoption-law-sayingit-discriminates-against-non-native-americans>. Accessed October 27, 2018.

"H.R.5237-Native American Graves Protection and Repatriation Act." Congress.gov. Online. <https://www.congress.gov/bill/101stcongress/house-bill/5237/text>. Accessed October 27, 2018.

“H.R.7356-Indian Claims Limitation Act of 1982." Congress.gov. Online. <https://www.congress.gov/bill/97th-congress/housebill/7356/text>. Accessed October 27, 2018.

"Indian Arts and Crafts Act of 1990." US Department of the Interior. Online. <https://www.doi.gov/iacb/act>. Accessed October 27, 2018.

Indian Country Today. Online. <https://newsmaven.io/indiancountrytoday/>. Accessed October 21, 2018. 
"Indian Gaming Regulatory Act." National Indian Gaming Commission. Online. <https://www.nigc.gov/general-counsel/indian-gaming-regulatory-act>. Accessed October 27, 2018.

Johnson, Troy R. Red Power: The Native American Civil Rights Movement. Infobase Publishing, 2007.

Kyrová, Lucie. "Native American International Activism and Political Thought during the Cold War, 1950-1989." Unpublished doctoral dissertation. Department of History, College of William and Mary, December 2015.

Klimke, Martin. The Other Alliance: Student Protest in West Germany o the United States in the Global Sixties. Princeton University Press, 2010.

Landry, Alysa. "Today in Native History: Natives Participate in Poor People's Campaign; Protest BIA." Indian Country Today, June 20, 2017. Online. <https://indiancountrymedianetwork.com/ history/events/today-native-history-natives-participatepoor-peoples-campaign-protest-bia/>. Accessed October 20, 2018.

Manuel, George, and Michael Posluns. The Fourth World: An Indian Reality. Collier-Macmillan Canada, 1974.

Matthiessen, Peter. In the Spirit of Crazy Horse. Viking Press, 1983.

Niezen, Ronald. The Origins of Indigenism: Human Rights and the Politics of Identity. University of California Press, 2003.

Records of the International Indian Treaty Council, San Francisco, California, USA.

Rosier, Paul C. Serving Their Country: American Indian Politics and Patriotism in the Twentieth Century. Harvard University Press, 2009.

Shreve, Bradley G. "From Time Immemorial: The Fish-in Movement and the Rise of the Intertribal Activism." Pacific Historical Review. 78.3 (2009): 403-434.

Smith, Paul Chaat and Robert Allen Warrior. Like a Hurricane: The Indian Movement from Alcatraz to Wounded Knee. The New Press, 1996.

Special Rapporteur on the Rights of Indigenous Peoples website. Online. <http://www.ohchr.org/EN/Issues/IPeoples/SRIn- 
digenousPeoples/Pages/SRIPeoplesIndex.aspx>. Accessed October 27, 2018.

Stern, Kenneth S. Loud Hawk: The United States versus the American Indian Movement. University of Oklahoma Press, 1994.

"Subchapter II-Indian Self-Determination and Education Assistance." Tribal Court Clearinghouse. Online. <https://www.tribal-institute.org/lists/pl93-638.htm>. Accessed October 27, 2018.

"S.2167-Native American Languages Act." Congress.gov. Online. <https://www.congress.gov/bill/101st-congress/senatebill/2167/text>. Accessed October 27, 2018.

Tóth, György. From Wounded Knee to Checkpoint Charlie: The Alliance for Sovereignty between American Indians and Central Europeans in the Late Cold War. State University of New York Press, 2016.

------. "Performing 'the Spirit of '76': US Historical Memory and Counter-Commemorations for American Indian Sovereignty." America: Justice, Conflict, War, edited by Amanda Gilroy and Marietta Messmer, Winter University Press, 2016, $131-150$

Trail of Broken Treaties 20-Point Position Paper. Documents. Framing Red Power website, by Jason A. Heppler. Online. <http:// www.framingredpower.org/archive/other/frp.tbt.19721027. xml>. Accessed October 20, 2018.

1968 Transnational Legacies

The United Nations Declaration on the Rights of Indigenous Peoples. March 2008. Online. <http://www.un.org/esa/socdev/unpfii/ documents/DRIPS_en.pdf>. Accessed October 27, 2018.

United Nations Permanent Forum on Indigenous Issues website. Online. <https://www.un.org/development/desa/indigenouspeoples/>. Accessed October 27, 2018.

“'We Also Have a Religion': The American Indian Religious Freedom Act and the Religious Freedom Project of the Native American Rights Fund." "Announcements." Native American Rights Fund. Winter 1979. Online. <https://www.narf.org/nill/documents/nlr/nlr5-1.pdf>. Accessed October 27, 2018.

Wiessner, Siegfried. "Introduction." United Nations Declaration on the Rights of Indigenous Peoples." Audiovisual Library 
of International Law. Online. <http://legal.un.org/avl/ha/ ga_61-295/ga_61-295.html>. Accessed October 27, 2018.

Wilkinson Charles. Blood Struggle: The Rise of Modern Indian Nations.

Norton, 2005.

Wilson, Brianna. "AIM Patrol, Minneapolis." MNOpedia. Online. <http:// www.mnopedia.org/group/aim-patrol-minneapolis >. Accessed October 20, 2018.

György Tóth

University of Stirling

United Kingdom

RIAS Associate Editor 
